\title{
パラチオン中毒時の尿中パラニトロフェノールの意義について
}

\author{
第 I 報 尿中バラニトロフェノール測定法の檢討
}

\section{On the Significance of p-Nitrophenol in Urine in Parathion Poisoning}

Report I. On the Determination Method of p-Nitrophenol in Urine

\author{
慶応義熟大学医学部衞生学公衆衞生学教室 (主任 原島進教授) \\ 高橋謙 \\ Ken Takahashi \\ Desartment of Preventive Medicine and Public Health, School of Medicine, Keio Unversity
}

(Director: Prof.S. Harashima)

有機燐殺虫剤 Parathion は農場, 果樹園等で昭和 27 年来多量江使用され，昭和 30 年度には死亡 510 名（内自 殺 462名), 重症中毒 118名, 中毒症 152名, 軽症 626名 を出している。との Parathion 中毒の診断方法として, 現在臨床症状によるもの, その抗コリンェステラーゼ作 用を目標とした血液コリンェステラーゼ活性值の低下に 上る診断と, Parathion の生体内分解産物であるパラ ニトロフェノールの尿中排泄を目標とした診断法等があ る。

血液コリンエステラーゼ(以下 $\mathrm{ChE}$ )活性值熦実な 診断方法であるが, その值の個人差が大きく, 各個人の

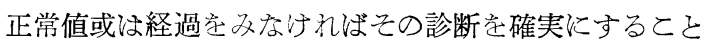
はできない久点がある。尿パラニトロフェノール（以下 PNP) 排泄量の測定は間接に体内に Parathion が吸 収された量を推定することができ，ChE 法と併用すれ ば中毒の診断を一層確実にすることができる。しかし独 立の診断法としての意義については未解決の 部分が多 い。本論交に扢いて注尿中P NPの測定方法の検討及び 改良について述べ, 種々の中毒時に打ける尿中P NPに ついて実験的追求を行い, その意義について考察する。

尿中 P N P の排泄量の測定はアルカリ性で P N P が黄 色調学呈するととを利用する方法と, 還元してアミノフ ェノールとし，フェノール類と縮合呈色さすインドフェ ノール法とに大別しうる。

後者の方法は Mountain と Zlotolow ${ }^{11}$ とよりまず報 告され, Waldman と Krause ${ }^{2)}$, 更に Lawford そ
Harvey ${ }^{3)}$ とより簡易化された。Mountain や Waldman 等は尿の色素导除くために種々の薬品 (Mountain は醋 酸鉛と燐酸, Waldman は塩化バリウム, 過マンガン酸 カリ, 蓚酸等)を使用し, Lawford 等は尿色素の移行しな い有機溶剤の追求をした。尿色素の脱色方法はその過程 に拀いてP NPの損失をきたす。たとえ浑 Waldman一 Krause の方法に扔いてはこの過程中に20 25\%が失わ れる(第1表)。しかも操作が複雑となり時間も多くか かる。従つて操作も簡単であり試薬も安価である Law-

\section{第 1 表 Waldman一Krause 法の尿固有色素脫色 の際に起るパラニトロフェノールの損失}

脱色法

第I段階：尿 $10 \mathrm{ml}$ K

$40 \% \mathrm{NaOH} 0.2 \mathrm{ml}$ を加元振湦 30 分 $25 \% \mathrm{BaCl} 5.0 \mathrm{ml}$ 間放置後遠沈分 $5 \% \mathrm{KMnO}_{4} 3.0 \mathrm{ml}$ 離

第 II 段階 : 上記の上清K

$10 \%$ 苳酸 $7.0 \mathrm{ml}$ を加元振擝放置遠沈

第 III 段階：上清より有機溶抄に抽出，次にアルカ

リ層に転溶,フェノールを加え三塩化

チタメで還元，呈色したインドフェノ

ール青を測定

\begin{tabular}{|c|c|c|c|}
\hline \multirow{2}{*}{$\begin{array}{l}\text { バラートロフェノール } \\
20 \mu \mathrm{g} \text { 添加の段階 }\end{array}$} & \multicolumn{3}{|c|}{ 吸 光 度 係 数 } \\
\hline & 尿 $\mathrm{A}$ & 尿 B & 尿 C \\
\hline 尿に加えた後 I, II, III & 0.066 & 0.072 & 0.070 \\
\hline I 段階後に加えた時 & 0.080 & 0.086 & 0.079 \\
\hline II段階後に加えた時 & 0.088 & 0.090 & 0.085 \\
\hline
\end{tabular}


ford一Harvey 法について検討を行い必要な改良を試み た。

\section{実 験}

Lawford-Harvey 法の原理は Parathion が体内(血 漿, 肝乞の他) で分解して生ずるPNPを尿から有機溶 郕で抽出し，アルカリ液 (アンモニア水等) に移行さ せ，亜鉛末等の還元剤を加えて還元してパラアミノフェ ノールとなし，とれに ○一クレゾール（またはフェノー ル）を加え縮合して生じるインドフェノールの呈色（青 色） $620 \mathrm{~m} \mu$ またはその付近で吸光度を測定定量する (第 1 図)。

\section{第 1 図 PNP のインドフェノール反応}

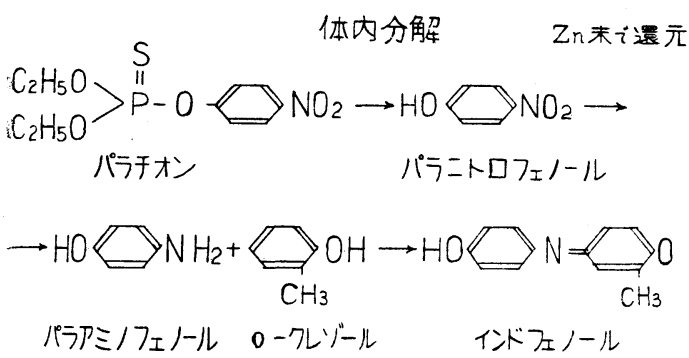

試 薬:

パラニトロフェノール標準液 $20 \mu \mathrm{g} / \mathrm{ml}$

濃塩酸 (G R)

アムモニア水 $(2 \mathrm{~N})$

混合溶剤 エチルエーテル 1 容

* 石油エーテル 4 容

これにイソアミルアルコール $1 \mathrm{~V} / \mathrm{V} \%$ \%加える

* 沸点 $40 \sim 60^{\circ} \mathrm{C}$.

亜銛末 (また注三塩化チタン)

o-ークレゾール溶液 1\%( $1 \mathrm{~g} / \mathrm{dl})$

器 具:

ピペット各種

$100 \mathrm{cc}$ 分離ロート（著者改良法では内容 50cc 共栓付 遠沈管)

10cc遠沈管

光電比色計 (フィルター $620 \mathrm{~m} \mu$ またはその付近) Lawford 原法の各段階検討しながら改良すべき点 も述べて行く,

\section{a) 前処置としての酸分解}

尿中に排泄される P N P は遊離の形《执いては原とえん ぞ存在せず，エーテル硫酸，グルクロン酸に抱合されて
おり塩酸等の酸性加熱により分解を行わなくては, 完全 に検出はできない。原法はこの前処置に全く触れていな い。

酸分解の濃塩酸の量と温度と時間：尿 (Parathion 粉剤工場工員の尿) と濃塩酸の比が $10 ： 1$ (本邦 慣用の濃度)の場合は $100^{\circ} \mathrm{C} 60$ 分で一定の値に達し加熱 時間を延長しても增加しない。10：3 とすると $100^{\circ} \mathrm{C} 180$ 分に至るもな抬呈色増加の過程にあつて一定值に達しな

\section{第 2 図 尿: 濃塩酸 $=10: 3$ の場合 加熱時間による酸分解の差}

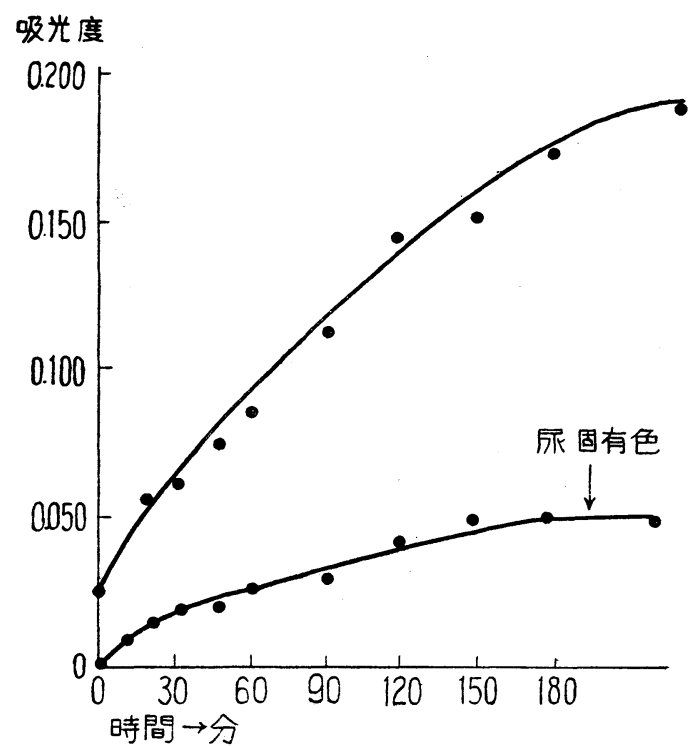

い(第 2 図)。加熱条件を $100^{\circ} \mathrm{C} 1$ 時間と限定した場合に は尿 $10 \mathrm{ml}$ に対し濃塩酸 $6 \sim 7 \mathrm{ml}$ で最高に達し(第 3 図 ),オートクレーブを用いる場合は $120^{\circ} \mathrm{C} 1$ 時間の加熱で 塩酸の濃度は10：2１0：6の範囲で一定の值を示し, $100^{\circ} \mathrm{C}$ 加熱の場合の最高値と一致する。乙れは同時に Fishman $^{4}$ の方法により同一尿のグルクロン酸を定量す るとグルクロン酸の増加と一致し, グルクロン酸抱合と いう裏付にもなる(第 2 表)。従つて加水分解条件として 尿 $10 \mathrm{cc}$ に対し濃塩酸 $6 \mathrm{ml}, 100^{\circ} \mathrm{C}, 60$ 分加熱で充分で あり，従来の慣用の $10 ： 1 ， 1$ 時間は約50\%を検出する に過ぎない(第 3 目)。な打酸分解として Brodie ${ }^{5}$ は 5 ： 1, $120^{\circ} \mathrm{C}, 90$ 分, Eicken ${ }^{6)}$ 性 $5: 1,100^{\circ} \mathrm{C}, 60$ 分を 行つている。まだ10：6の加熱分解で P N P は変化し ない。

\section{b) 抽出溶剂}

分解後冷却するのを待つて, 試薬の項に述べた混合溶 


\section{第 3 図 $100^{\circ} \mathrm{C}, 60$ 分，尿 $10 \mathrm{ml}$ に対する \\ 濃塩酸の多少による酸分解の差}

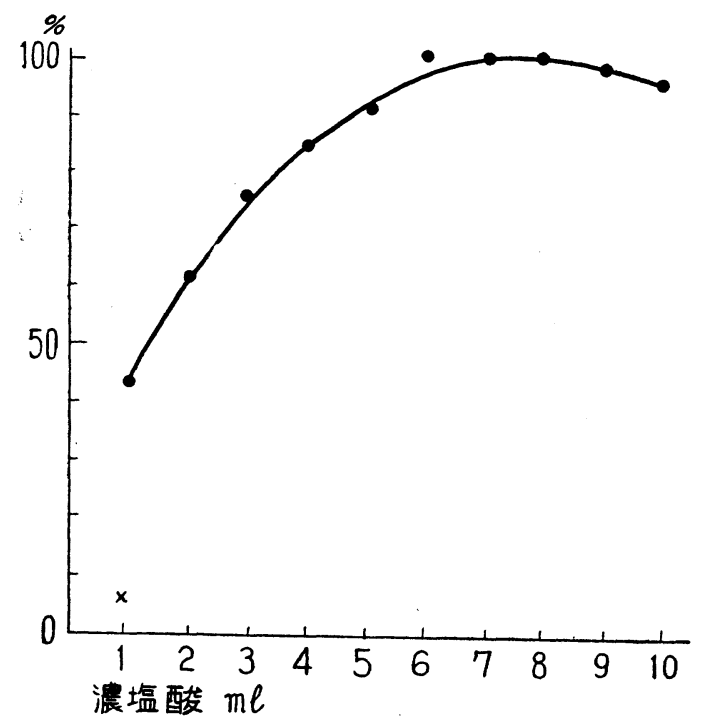

\section{第 2 表 酸分解時間による尿中パラニトロフェ ノール, タルクロン酸の検出}

尿: 濃塩酸 $=10: 3$

\begin{tabular}{r|c|c}
\hline & $\begin{array}{c}\text { パラニトロ } \\
\text { フェール }\end{array}$ & グルクロン酸 \\
\hline $100^{\circ} \mathrm{C} 1$ 時間 & 0.180 & 0.125 \\
$2 "$ & 0.232 & 0.185 \\
3 " & 0.254 & 0.220 \\
$120^{\circ} \mathrm{C} 1$ 時間 & 0.279 & 0.240 \\
\hline
\end{tabular}

尿: 濃塩酸 $=10: 6,100^{\circ} \mathrm{C} 1$ 時間で PNP $0.281,120^{\circ} \mathrm{C} 1$ 時間 0.280

剂孛試料 $10 \mathrm{ml}$ に対し $25 \mathrm{ml}$ 劣加元約 10 分間 (5 分以上 绀差はない）振盪抽出する。混合溶㶡のエーテル゚の比が 大なる時は尿色素の移行が多くまた抽出率もよい。石油 エーテルの多い場合は尿色素の移行も少いが抽出率も少 い(第 4 図)。またエーテルの多い場合は安定な均等液を つくりやすいのでェーテル, 石油エーテルの混合比は原 法通り $1: 4$ がよい。

\section{c) アルカリ転溶}

抽出後（液層はよく分離するが要すれば軽く遠沈し） 混合溶剂 $25 \mathrm{ml}$ 中 $20 \mathrm{ml}$ をとる。2 回抽出, 混合溶剤計 $40 \mathrm{ml}$ をとり，とれを $2 \mathrm{~N}$ をムモニア水 $10 \mathrm{ml}$ で10分間 振盪抽出する。

原法では酸分解を行わないので色素形成が少かつた が, 酸分解安行つた時は相当の暗褐色の色素を形成しア

\section{第 4 図 混合溶剂混合率の差によるパラニトロ フェノール，尿色素の抽出の差 \\ （尿は酸分解をしたるの）}

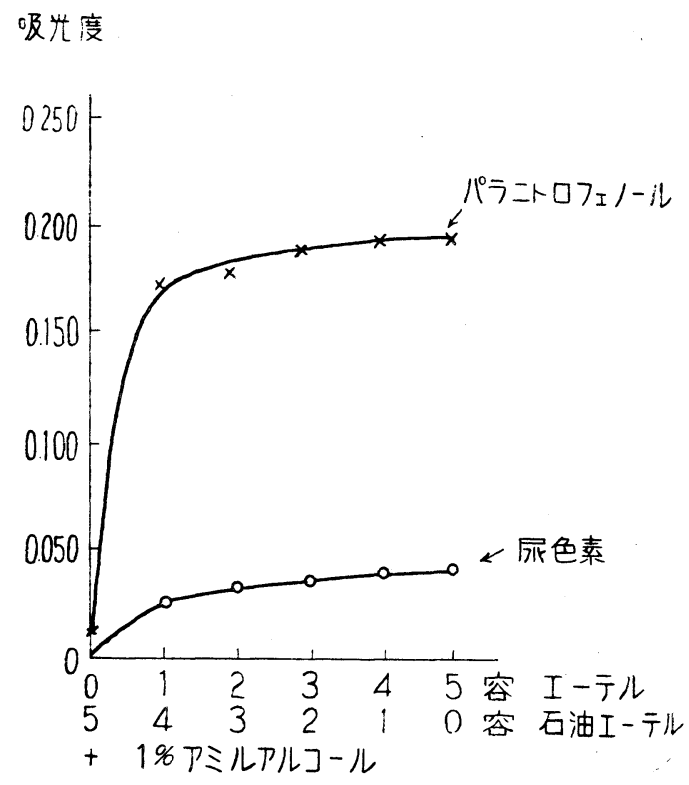

ルカリ液に一部移行する。その対策として原法ではアム モニア液 $5 \mathrm{ml}$ を用いるととろを $10 \mathrm{ml}$ 学使用, 転溶後 2 分し一方を対照管として使用する。10 ml メスピペッ トで混合溶風こ分離したアムモニア層（PNPが多けれ ば黄色）を $10 \mathrm{ml}$ こり $10 \mathrm{ml}$ 遠沈管にそれぞれ $5 \mathrm{ml}$ つ分注する。この場合, 混合溶剤が少し混入してもさし つかえない。ただし還元剤として亜鉿末の代りに三塩化 チタンを使用する場合には混合溶風が入ると安定な膠状 溷濁を生じて除去しにくいから，むしろ $10 \mathrm{ml}$ 中 $9 \mathrm{ml}$ を己り $4.5 \mathrm{ml}$ ずつ分注した方が安全である。

\section{d) 還元及び縮合}

還元は強アルカリ性（pH 11）で行うが，著者改良法 に従い酸分解で用いる濃塩酸を増量したための酸の移行 による $\mathrm{pH}$ の低下は僅少 (一pH 0.4) K止る。アムモ ニア液定分注した一管に $1 \% \mathrm{o}$ ークレゾール液 $0.5 \mathrm{ml}$ を他方 (対照管) に蒸溜水 $0.5 \mathrm{ml}$ を入れ亜鋁末 $0.5 \mathrm{~g}$ 当加えょく振盪 (1 分以上) 後遠沈 (15分) を行い上清 定傾斜分離し 1 時間後対照管を $100 \%$ とし $620 \mathrm{~m} \mu$ のフ ィルターを用いて, 吸光度を計り標準曲線よりその含量 を定める。Lawford 原法では亜鉛末で還元，分離後oクレゾール夜を加え呈色さ点るように指示してあるが, 実際儿は還元，遠沈分離より ○一クレゾール液を加える までの時間により呈色の差䘮生ずる（第 5 図）。0-ク 


\section{第 5 図 亞鉛末で還元遠沈分離後 1\% オルトクレソール溶液を加える までの時間による発色の差}

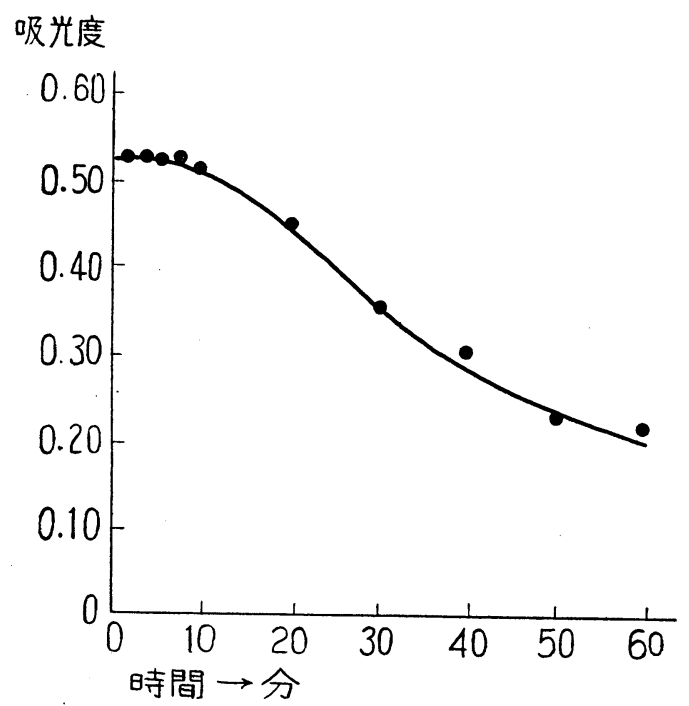

レゾール液を還元前か同時または遠沈分離前に加えれば 常に一定值を得る。遠沈は濾過で代用しろる。

還元凨として亜鉛末の代りに Waldman ${ }^{21}$, Eicken ${ }^{6)}$, 佐々木7 等の如く三塩化チタンを用いるのも良法であ る。三塩化チタン液（市販 $15 \% \mathrm{TiCl}_{3}$ 溶液 $0.6 \mathrm{ml}$ 水 で $10 \mathrm{ml}$ に稀橎） $0.5 \mathrm{ml}$ 交加え色がなくなるまで強く 振䔽後遠沈する。○ークレゾールを添加する時期ね亜鉛 末法と同様である。本剤の特色高鉛末法に比し, 速や 玑少くとも15分後呈色が極大に達し安定するととであ る。

\section{e) 標準曲線の作製}

正常尿をとり $10,20,30 \mu \mathrm{g} / 10 \mathrm{ml}$ の標準液をつくる （標準原液：P N P $1000 \mathrm{~g}$ を水 $500 \mathrm{ml}$ に溶かし, こ の $10 \mathrm{ml}$ を水で $1000 \mathrm{ml}$ とし, 乙の標準原液 $(20 \mu \mathrm{g} / \mathrm{ml})$ $0.5,1.0,0.5 \mathrm{ml}$ をとり 正常尿で $10 \mathrm{ml}$ にする。上 記の 全経過を 追つて吸光度を 測定し標準直線を作製す る。抽出遠沈その他の損失及び換算率等は標準曲線の中 に含まれる。稀釈の目的で尿の代りに通常の如く蒸溜水 を用いてもよいが，乙の場合混合溶㓮抽出率が尿に比較 して良好であるので, この補正が必要である。定量至適 範囲は通常の光電比色計でアムモニア溶液 $5 \mathrm{ml}$ 中 0.2 $\sim 40 \mu \mathrm{g}$ 。著者の 改良法认尿固有色（盲検值）を相殺す るために対照管を置く必要上アムモニア夜10ccに転溶さ す。との場合泳としてての 2 倍の濃度を含有するか， 或は 2 倍量の尿 $(20 \mathrm{ml})$ 学試料とする必要がある。呈
色したインドフェノール青色は45分より 3 時間は安定で ある。

また山村8) は簡易法として肉眼的比色の目的でアムモ ニア性硫酸銅の標準管を作製し，その色調がインドフェ ノール青と極めて一致して実用に供しうるととを発表し ている。

\section{f）手技上の改辰}

試料の数が極く少い時はよいが，パラチオン粉剤工場 工員, 集団撒布時の農民を対象とするょうな多数の試料

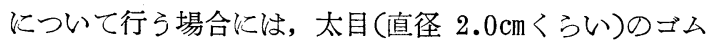
栓付試験管に尿を $30 \sim 40 \mathrm{ml}$ くらいとらせる。前処理と 抽出分離を同一容器で行うために $50 \mathrm{ml}$ 共栓付遠沈管に 尿 $10 \mathrm{cc}$ 濃塩酸 $6 \mathrm{ml}$ を入れ栓をし, 栓のとばぬように七 ロファンで被い輪ゴムで止め10本或ば。20本をまとめ重湯 煎中で加熱分解, 冷却後混合溶剤を $25 \mathrm{ml}$ 加え振盪抽出 する。この後静置により液層が分離しない時があるが遠 沈により容易に分離できる。とのように分離ロートを使 用するょり操作が簡単になる。

尿はできるだけ新しい方がよく，保存する場合は一定 量の濃塩酸を加えるか, 冷蔵庫内に保存するととが必要 である。

\section{総 括}

パラチオン吸収によるパラニトロフェノール（PNP） 定量法を検討して次の結論学得た。

1) Lawford一Harvey 法は最も優り Mountain 等, Waldman 等の方法は脱色前処理中に損失があり, 繁雑 である。

2）Lawford 等の原法によつては グルクロン酸と抱 合したPNPを定量しえない。尿と濃塩酸の比を $5 ： 3$ として $100^{\circ} \mathrm{C}, 1$ 時間加熱で極大值を得る。

3）抽出溶剤の ェーテルと石油ェーテルの比は原法 (1：4）が最良である。

4）アルカリ抽出は原法の 2 倍のアムモニア液を用 い, その半分を呈色せしめずに対照管として用い盲検值 を打消さす。

5）還元後の呈色操作に㧈いて，原法の如く亜鉛末を 遠沈した後に oークレゾールを加えると呈色は不定とな る。遠沈前に ○一クレゾールを加え, 数分後に遠沈する 必要がある。

6） 1 試料に対し $50 \mathrm{ml}$ 共栓付遠沈管 2 本を用い, 加 熱前処理, 溶媒抽出, アルカリ抽出を行うのが能率的で ある。 
御指導, 御校閲を賜わつた原島教授及び上田助教授に 深謝いたします。

本論交の 要旨は第 9 回日本産業医学会（昭和 29 年 4 月）改び農林省報告"', 厚生省報告に発表した。

\section{文献}

1) Mountain, J. T. ; Zlotolow, H. and O'Connors, G. T.: Indust. Health Month. 11: 88, 1951.

2) Waldman, R. K. and Krause, L. A.: Occup. Health $12: 37,1952$.

3) Lawford, D. J. and Harvey, D. G.: Analyst. $78: 63,1953$.
4) Fishman, W. H. et al.: J. Clinic. Invest. $30: 7,1951$.

5) Brodie, B. B. and Axelord, J.: J. Pharm. \& Exp. Therap. $94: 22,1948$.

6) Eicken, v. S.: Angew. Chem. $66: 551$, 1954.

7 ）佐队木直亮他：日本公衆衞生誌 $1: 400,1954$.

8 ) 山村醇一：厚生省編, 有機燐剂の薬理作用と化 学的性質 P. 17, 1955.

9 ）農薬中毒研究班：新農薬の人畜に対する影響に 関する研究, 第 3 中間報告 1953 , 第 5 中間報告 1955.

（受付：1956年 5 月 22 日） 